\title{
In vitro ability of beer fermentation residue and yeast-based products to bind aflatoxin $\mathrm{B}_{1}$
}

\author{
Fernanda Bovo ${ }^{1}$, Larissa Tuanny Franco ${ }^{1}$, Roice Eliana Rosim ${ }^{1}$, Ricardo Barbalho ${ }^{2}$, \\ Carlos Augusto Fernandes de Oliveira ${ }^{1}$ \\ ${ }^{1}$ Departamento de Engenharia de Alimentos, Faculdade de Zootecnia e Engenharia de Alimentos, \\ Universidade de São Paulo, Pirassununga, SP, Brazil. \\ ${ }^{2}$ ICC Brazil, São Paulo, SP, Brazil.
}

Submitted: April 23, 2013; Approved: September 5, 2014.

\begin{abstract}
This study aimed to verify the in vitro ability of beer fermentation residue (BFR) containing Saccharomyces cerevisiae cells and five commercial products that differed in the viability and integrity of $S$. cerevisiae cells to remove aflatoxin $\mathrm{B}_{1}\left(\mathrm{AFB}_{1}\right)$ from a citrate-phosphate buffer solution (CPBS). BFR was collected at a microbrewery and prepared by drying and milling. The commercial yeast-based products were as follows: inactive intact yeast cells from beer alcoholic fermentation, inactive intact yeast cells from sugarcane alcoholic fermentation, hydrolyzed yeast cells, yeast cell walls and active yeast cells. Adsorption assays were performed in CPBS spiked with $1.0 \mu \mathrm{g}$ $\mathrm{AFB}_{1} / \mathrm{mL}$ at $\mathrm{pH} 3.0$ and 6.0 for a contact time of $60 \mathrm{~min}$ at room temperature. Analysis of $\mathrm{AFB}_{1}$ in the samples was performed by high performance liquid chromatography. $\mathrm{AFB}_{1}$ adsorption by the products ranged from $45.5 \%$ to $69.4 \%$ at $\mathrm{pH} 3.0$ and from $24.0 \%$ to $63.8 \%$ at $\mathrm{pH} 6.0$. The higher percentages $(\mathrm{p}<0.05)$ of $\mathrm{AFB}_{1}$ binding at both $\mathrm{pH}$ values were achieved with products containing hydrolyzed yeast cells or yeast cell walls rather than intact cells. The $\mathrm{AFB}_{1}$ binding percentages of BFR were $55.0 \pm 5.0 \%$ at $\mathrm{pH} 3.0$ and $49.2 \pm 4.5 \%$ at $\mathrm{pH} 6.0$, which was not significantly different $(p>0.05)$ from commercial products containing inactive intact yeast cells. The results of this trial indicate that the yeast-based products tested, especially the BFR, have potential applications in animal feeds as a suitable biological method for reducing the adverse effects of aflatoxins.
\end{abstract}

Key words: $\mathrm{AFB}_{1}$, binding capacity, decontamination, S. cerevisiae cells.

\section{Introduction}

Aflatoxin $\mathrm{B}_{1}\left(\mathrm{AFB}_{1}\right)$ is the main metabolite produced by fungi of the genus Aspergillus, primarily A. flavus and $A$. parasiticus, which can contaminate corn, sorghum, oilseeds, and other food materials (An, 2005). Various domestic and experimental species are sensitive to the carcinogenic, mutagenic, hepatotoxic and immunosuppressive effects of $\mathrm{AFB}_{1}$, in which the liver is the main affected organ (Hussein and Brasel, 2001).

Concern about the negative impacts of $\mathrm{AFB}_{1}$ on animal health and the agricultural economy led to an investigation of strategies to prevent their formation, as well as to eliminate, inactivate or reduce their bioavailability in con- taminated products (Hernandez-Mendoza et al., 2009). Enteroadsorption methods use nutritionally inert dietary compounds that prevent toxin absorption by the animal gastrointestinal tract (Gratz et al., 2005). Although several mineral adsorbents are available, their application is limited due to vitamin and mineral adsorption (Hussein and Brasel, 2001). An attractive alternative is the use of microorganisms to control or eliminate aflatoxins $(\mathrm{AF})$ in food and feed, thus preserving their quality and safety (Alberts et al., 2009).

The adsorptive capacity of yeast cells has been widely studied, and yeast is a promising candidate for AF decontamination (Aravind et al., 2003; Fruhauf et al., 2012; Stan- 
ley et al., 2004). Commercial products made from either whole yeast cells or partial yeast cells, such as cell wall glucans and mannans, are used in animal rations not only to facilitate toxin adsorption but also to improve productivity parameters. Unlike the yeast cells used in ethanol fuel production from sugar cane, which are often reused throughout the season, the yeast cells used in beer production are discharged at the end of each process. In addition to its excellent nutritional value, yeast biomass from beer fermentation has been hypothesized to be a viable alternative for removing $\mathrm{AF}$, especially considering its wide availability both worldwide and in Brazil. Therefore, the objective of this study was to perform in vitro tests to verify the ability of beer fermentation residue to remove $\mathrm{AFB}_{1}$ from a citrate-phosphate buffer solution and to then compare the results with those found for five commercial products made from yeast cells.

\section{Materials and Methods}

\section{Yeast cell based products}

Beer fermentation residue (BFR) containing cells of Saccharomyces cerevisiae was obtained from a microbrewery located in the State of São Paulo, Brazil. BFR was collected and transported to the Laboratory of Food Microbiology and Mycotoxicology (College of Animal Science and Food Engineering, University of São Paulo), and the number of yeast cells was counted using a Neubauer chamber (BOE13 - Boeco, Hamburg, Germany). Convenient volumes of BFR $(4.0 \mathrm{~L})$ containing $10^{10}$ cells $/ \mathrm{mL}$ were transferred to aluminum pans for drying in an oven with forced air circulation (320-SE - Fanem, São Paulo, SP, Brazil) at $100^{\circ} \mathrm{C}$ to constant weight to obtain a dry mass of BFR containing $S$. cerevisiae cells. The dried residue was ground in a mill (TE-631/2 - Tecnal, Piracicaba, SP, Brazil) and stored at room temperature for further use in the in vitro $\mathrm{AFB}_{1}$ adsorption assays.

Adsorption tests of $\mathrm{AFB}_{1}$ were also performed using five commercial yeast-based products containing $S$. cerevisiae cells or part of these cells, as described in Table 1. Products numbered from 2 to 5 were produced and kindly donated by ICC Brazil (São Paulo, SP, Brazil). Product number 6 (SAFLAGER W37/70) was acquired from Fermentis Ltd. (Marcq en Baroeul, France).

\section{Adsorption Assays of $\mathrm{AFB}_{1}$}

A standard of $\mathrm{AFB}_{1}$ (Supelco, Bellefonte, PA, USA) was dissolved in toluene and acetonitrile (9:1), calibrated in a spectrophotometer (Spectrumlab 22PC - Shanghai Lengguang Technology Co. Ltd, Shanghai, China) according to Scott (1990), and diluted to obtain a stock solution containing approximately $10.0 \mu \mathrm{g} \mathrm{AFB} / \mathrm{mL}$. The previous solution was used in the preparation of other working solutions containing approximately $1.0 \mu \mathrm{g} \mathrm{AFB}_{1} / \mathrm{mL}$ in a citrate-phosphate buffer solution $(\mathrm{pH} 3.0$ and $\mathrm{pH}$ 6.0)
Table 1 - Yeast-based products containing cells of S. cerevisiae used in the $\mathrm{AFB}_{1}$ adsorption assays.

\begin{tabular}{|c|c|c|}
\hline Product & Identification & Description \\
\hline 1 & $\mathrm{BFR}^{1}$ & $\begin{array}{l}\text { Residue from beer alcoholic fermen- } \\
\text { tation }\end{array}$ \\
\hline 2 & BFIY $^{2}$ & $\begin{array}{l}\text { Inactive yeast cells from beer alco- } \\
\text { holic fermentation }\end{array}$ \\
\hline 3 & SFIY $^{2}$ & $\begin{array}{l}\text { Inactive yeast cells from sugarcane } \\
\text { alcoholic fermentation }\end{array}$ \\
\hline 4 & Hilyses $^{2}$ & Hydrolyzed yeast cells \\
\hline 5 & ImmunoWall $^{2}$ & Yeast cell walls \\
\hline 6 & Saflager $^{3}$ & $\begin{array}{l}\text { Active yeast cells from beer alcoholic } \\
\text { fermentation }\end{array}$ \\
\hline
\end{tabular}

${ }^{1}$ Beer fermentation residue collected at a microbrewery in São Paulo, Brazil, and prepared in the laboratory by drying and milling.

${ }^{2}$ Yeast-based products produced by ICC Brazil (São Paulo, SP, Brazil).

${ }^{3}$ Yeast $S$. cerevisiae SAFLAGER W37/70 produced by Fermentis Ltd. (Marcq en Baroeul, France).

prepared using a combination of solutions of $0.1 \mathrm{M}$ citric acid (Synth, Diadema, SP, Brazil) and 0.2 M bibasic sodium phosphate (Süd Chemie, Jacareí, SP, Brazil). The solvent was completely evaporated by direct injection of air over a heating bath at $40{ }^{\circ} \mathrm{C}$ (TE-019 -Tecnal, Piracicaba, SP, Brazil).

The assays evaluating the efficiency of adsorbents to remove $\mathrm{AFB}_{1}$ from a contaminated medium were conducted at $\mathrm{pH}$ of 3.0 and 6.0 according to Ledoux and Rottinghaus (1999). For each $\mathrm{pH}, 0.05 \mathrm{~g}$ of each sample was weighed and suspended in $5 \mathrm{~mL}$ of buffer solution (pH 3.0 or $\mathrm{pH}$ 6.0) spiked with $\mathrm{AFB}_{1}$ and incubated in an orbital shaker (TE-140 - Tecnal, Piracicaba, SP, Brazil) at $180 \mathrm{rpm}$ for $60 \mathrm{~min}$ at room temperature. Following this step, centrifugation was performed at $1,800 \mathrm{x}$ g for $10 \mathrm{~min}$ (CT-14000 - Cientec, Piracicaba, SP, Brasil), and then $2 \mathrm{~mL}$ of the supernatant was collected and stored at $-20^{\circ} \mathrm{C}$ for a subsequent injection into the High Performance Liquid Chromatography (HPLC) system. The assays were performed in triplicate, and we also incubated and analyzed a positive $\left(\mathrm{AFB}_{1}\right.$ in buffer solution) and negative $(0.05 \mathrm{~g}$ of sample in buffer solution) control.

\section{Quantification of $\mathrm{AFB}_{1}$ by HPLC}

$\mathrm{AFB}_{1}$ quantification in the buffer solutions was achieved by direct injection into a Shimadzu HPLC (Tokyo, Japan) system consisting of a fluorescence detector (RF-10A XL) and an autosampler (SIL-10AF). An ODS column $5 \mu \mathrm{m} 4.6$ X $150 \mathrm{~mm}$ (Phenomenex, Torrance, CA, USA) was used. The system was stabilized for one hour at a flow rate of $1 \mathrm{~mL} / \mathrm{min}$ at room temperature. The mobile phase was a solution of water, acetonitrile and methanol (60:20:20) at a flow rate of $1 \mathrm{~mL} / \mathrm{min}$. The excitation detection was performed at a wavelength of $360 \mathrm{~nm}$, and emission was monitored at $440 \mathrm{~nm}$. Under the above conditions, the detection limit for $\mathrm{AFB}_{1}$ was $0.01 \mathrm{ng} / \mathrm{mL}$, and the reten- 
tion time was approximately 10.5 min with a retention window of $\pm 10 \%$.

The quantification of the percentage of $\mathrm{AFB}_{1}$ adsorbed was performed using Eq. 1, where A represents the percentage of $\mathrm{AFB}_{1}$ adsorbed by the sample, $\mathrm{B}$ the area of positive control chromatographic peak $\left(\mathrm{AFB}_{1}\right.$ in buffer solution), $\mathrm{C}$ the area of sample chromatographic peak $\left(\mathrm{AFB}_{1}\right.$ in buffer solution + sample) and $\mathrm{D}$ the area of negative control chromatographic peak (buffer solution + sample).

$$
A=\frac{B-C-D}{B} * 100
$$

\section{Statistical analysis}

The results were subjected to ANOVA in accordance with the procedures established in the General Linear Model of SAS (1992) to assess significant differences between the means of variables in the different treatments. For comparison between means, we used the Fisher LSD test and adopted a rejection level of $\alpha=0.05$.

\section{Results and Discussion}

The results obtained for $\mathrm{AFB}_{1}$ adsorption efficiency by BFR and commercial yeast-based products in a contaminated medium are presented in Table 2 . The percentages of toxin adsorption by all products ranged from $45.5 \%$ to $69.4 \%$ at $\mathrm{pH} 3.0$ ( $\mathrm{p}<.0001)$ and from $24.0 \%$ to $63.8 \%$ at $\mathrm{pH}$ $6.0(P<.0001)$. The Hilyses and ImmunoWall products had the best capacity to adsorb $\mathrm{AFB}_{1}$ at both $\mathrm{pH}$ values and were quite similar $(p>0.05)$. BFR bound the toxin at $55.0 \%$ at $\mathrm{pH} 3.0$ and $49.2 \%$ at $\mathrm{pH} 6.0$, which did not differ significantly from products BFIY and SFIY but did have greater values than the Saflager product at $\mathrm{pH} 3.0$ or 6.0 . Only products BFIY $(\mathrm{p}=0.0212)$, Hilyses $(\mathrm{p}=0.0256)$ and Saflager $(p=0.0003)$ differed significantly when compared at different $\mathrm{pH}$ values.

Jouany et al. (2005) explained that the $S$. cerevisiae cell wall is composed mainly of polysaccharides $(80-90 \%)$ and that their mechanical strength is due to an inner layer formed by chains of $\beta$-D-glucans. These $\beta$-D-glucans are composed of a complex network of $\beta$-(1,3)-D-glucans with a high degree of polymerization branched with $\beta-(1,6)$ D-glucans with a low degree of polymerization. This inner layer is firmly bound to the plasma membrane by linear chains of chitin, which has a significant role in the insolubility of the overall structure of the cell and in the packaging of $\beta$-D-glucans, both of which influence the plasticity of the cell wall. The outer layer of the yeast cell wall is composed of mannoprotein, which plays an important role in gas and nutrient exchange with the outside environment. The entire structure is highly dynamic and can vary with the yeast strain, phase of cell cycle, and growth conditions such as $\mathrm{pH}$, temperature, oxygenation rate, medium nature and carbon source. Thus, such differences in cell wall composi-
Table 2 - $\mathrm{AFB}_{1}$ adsorption results of $S$. cerevisiae cell based products in citrate-phosphate buffer solution.

\begin{tabular}{lccc}
\hline Products $^{1}$ & \multicolumn{2}{c}{ Aflatoxin $\mathrm{B}_{1}$ Adsorbed $^{2}(\%)$} & \multirow{2}{*}{ p value } \\
\cline { 2 - 3 } & $\mathrm{pH} 3.0$ & $\mathrm{pH} 6.0$ & \\
\hline BFR & $55.0 \pm 5.0^{\mathrm{b}}$ & $49.2 \pm 4.5^{\mathrm{b}}$ & 0.2096 \\
BFIY & $56.3 \pm 4.2^{\mathrm{b}}$ & $45.9 \pm 2.5^{\mathrm{b}}$ & 0.0212 \\
SFIY & $53.2 \pm 2.0^{\mathrm{b}}$ & $49.7 \pm 2.6^{\mathrm{b}}$ & 0.1351 \\
Hilyses & $69.4 \pm 0.9^{\mathrm{a}}$ & $60.0 \pm 4.6^{\mathrm{a}}$ & 0.0256 \\
ImmunoWall & $66.7 \pm 2.6^{\mathrm{a}}$ & $63.8 \pm 1.2^{\mathrm{a}}$ & 0.1578 \\
Saflager & $45.5 \pm 2.8^{\mathrm{c}}$ & $24.0+1.3^{\mathrm{c}}$ & 0.0003 \\
\hline
\end{tabular}

${ }^{1}$ BFR: Inactive yeast cells from beer alcoholic fermentation dried and milled; BFIY: Inactive yeast cells from beer alcoholic fermentation; SFIY: Inactive yeast cells from sugarcane alcoholic fermentation; Hilyses: Hydrolyzed yeast cells; ImmunoWall: Yeast cell walls; Saflager: Active yeast cells from beer alcoholic fermentation.

${ }^{2}$ Values expressed as mean \pm standard deviation of samples analyzed in triplicate.

${ }^{\mathrm{a}-\mathrm{c}}$ Within a column, means without a common superscript differ significantly $(\mathrm{p}<0.05)$.

tion among yeast strains may have influenced the ability of the tested products to bind $\mathrm{AFB}_{1}$ in the present study because all products included $S$. cerevisiae cells in their composition but were composed of different strains of the same yeast species.

$\beta$-D-glucans are the cell wall components responsible for complexation with the toxin, and the reticular organization of $\beta$-D-glucans and their distribution among $\beta$ - $(1,3)$ and $\beta$-(1 6)-D-glucans plays an important role in this efficacy. In addition, weak hydrogen bonds and van der Waals bonds are involved in the complex chemical formation between mycotoxins and $\beta$-D-glucans, leading to a chemical interaction of "adsorption" rather than "contact". Regarding $\mathrm{AFB}_{1}$, the toxin is bound to the glucans due to the interaction between the aromatic ring and the lactone and ketone groups of the polar form of $\mathrm{AFB}_{1}$, as well as by chemical bonds with glucose units of the single helix $\beta$-D-glucans. Thus, the separation of the yeast cell wall from other cellular components, such as the cytoplasm and organelles, or the hydrolysis of the cell may expose a greater number of $\beta$-D-glucan units that were not previously available when the yeast cell was intact (Jouany et al., 2005). These structural changes cause an increase in mycotoxin removal from the medium, which could possibly explain why the products Hilyses and ImmunoWall had a greater degree of $\mathrm{AFB}_{1}$ removal at $\mathrm{pH} 3.0$ and 6.0. However, HernandezMendoza et al. (2009) found that the integrity of the bacterial cell wall plays an important role in the process of AF removal by either viable or non-viable cells. In their study it was shown that both the bacterial cell wall and its purified fragments were able to remove the $\mathrm{AF}$ from the medium; however, when the cell wall was lost or destroyed due to 
enzymatic treatments, a significant reduction in removal capacity was observed.

Fruhauf et al. (2012) analyzed 30 commercial products composed of different concentrations of yeast cell walls and inorganic compounds and found that a higher ash content corresponded to lower mannan-oligosaccharide and $\beta$-glucan content. The authors concluded that the effectiveness of $\mathrm{AFB}_{1}$ removal was related to the ash content because eight products with over $30 \%$ of ash had toxin adsorption values over $90 \%$, while eight of ten products with less than $10 \%$ ash showed adsorption rates lower than $25 \%$ in all tested mediums ( $\mathrm{pH} 3.0$ and 6.0 and gastric juice).

As mentioned before, we observed significant differences between the values of $\mathrm{AFB}_{1}$ adsorption at $\mathrm{pH} 3.0$ and 6.0 for the BFIY, Hilyses and Saflager products. Raju and Devegowda (2002) did not observe differences between $\mathrm{pH}$ values when using esterified glucomannan, a yeast cell wall derivative, at a rate of $0.1 \%$ for $\mathrm{AFB}_{1}$ removal $(300 \mathrm{ppb})$ (80.7\% and $82.5 \%, \mathrm{pH} 3.0$ and 6.0, respectively). Diaz et al. (2002) found no differences in the removal of $\mathrm{AFB}_{1}$ by esterified glucomannan $(96.6 \%)$ between the $\mathrm{pH}$ values analyzed ( $\mathrm{pH} 3,7$, and 10; $\mathrm{pH}$ not adjusted after the addition of $1 \%$ of the product).

Using intact and viable cells of $S$. cerevisiae, Armando et al. (2011) observed percentages of $\mathrm{AFB}_{1}$ $(500 \mathrm{ng} / \mathrm{mL})$ removal between 20.2 and $65.5 \%$, depending on the yeast strain. Shetty et al. (2007) analyzed 18 strains of viable S. cerevisiae from fermented corn dough and sorghum beer production and found that seven strains removed $10-20 \%$ of $\mathrm{AFB}_{1}, 8$ strains removed $20-40 \%$ and three strains removed more than $40 \%$, again emphasizing the importance of the strain. These results were similar to those found in our study for the intact and viable cells present in the product Saflager $(45.5 \%$ and $24.0 \%$, respectively for $\mathrm{pH} 3.0$ and 6.0).

Products containing inactive and intact yeast cells (BFIY, SFIY and BFR) presented greater values for $\mathrm{AFB}_{1}$ adsorption than the product containing active and intact yeast cells (Saflager). Cellular non-viability obtained by heating may increase the permeability of the outer yeast cell wall due to both the suspension of mannans from the cell surface and many physical and chemical changes, leading to increased availability of previously hidden binding sites. The continuity of AF removal, even after application of heat treatments, confirms once more that yeast cell viability is not a significant factor in the removal of toxins from the medium (Rahaie et al., 2010).

The results of this trial indicated that all the tested yeast-based products containing cells of $S$. cerevisiae have the ability to partially remove $\mathrm{AFB}_{1}$ in vitro. The binding process was dependent on the conditions in which yeast cells were produced, including the viability and integrity of these cells as well as the specificity of each strain. Thus, we conclude that the yeast-based products tested, especially the BFR, have a potential application in animal feeds as a suitable biological method for reducing the adverse effects of AF. However, additional in vivo experiments are needed to confirm the viability of using BFR and other yeast-based products as adsorbents in animal feeds.

\section{Acknowledgments}

The authors thank the financial support of FAPESPFundação de Amparo à Pesquisa do Estado de São Paulo, Brazil (Grant Number: 2011/03410-0).

\section{References}

Alberts JF, Gelderblom WCA, Botha A et al. (2009) Degradation of aflatoxin $\mathrm{B}_{1}$ by fungal laccase enzymes. Int J Food Microbiol 135:47-52.

An Z (2005) Handbook of industrial mycology. Marcel Dekker, New York, N.Y.

Aravind KL, Patil VS, Devegowda G et al. (2003) Efficacy of esterified glucomannan to counteract mycotoxicosis in naturally contaminated feed on performance and serum biochemical and hematological parameters in broilers. Poult Sci 82:571-576.

Armando MR, Dogi CA, Pizzolitto RP et al. (2011) Saccharomyces cerevisiae strains from animal environment with in vitro aflatoxin $\mathrm{B}_{1}$ binding ability and anti-pathogenic bacterial influence. World Mycotoxin J 4:59-68.

Diaz DE, Hagler Jr WM, Hopkins BA et al. (2002) Aflatoxin binders I: In vitro binding assay for aflatoxina $\mathrm{B}_{1}$ by several potential sequestering agents. Mycopathologia 156:223226.

Fruhauf S, Schwartz H, Ottner F et al. (2012) Yeast cell based feed additives: studies on aflatoxina $\mathrm{B}_{1}$ and zearalenone. Food Addit Contam Part A 29:217-231.

Gratz S, Mykkänem H, El-Nezami H (2005) Aflatoxin B B binding by a mixture of Lactobacillus and Propionibacterium: in vitro vs. ex vivo. J Food Prot 68:2470-2474.

Hernandez-Mendoza A, Garcia HS, Steele JL (2009) Screening of Lactobacillus casei strains for their ability to bind aflatoxin $B_{1}$. Food Chem Toxicol 47:1064-1068.

Hussein HS, Brasel JM (2001). Toxicity, metabolism, and impact of mycotoxins on humans and animals. Toxicology 167:101-134.

Jouany JP, Yiannikouris A, Bertin G (2005) The chemical bonds between mycotoxins and cell wall components of Saccharomyces cerevisiae have been identified. Arch Zootec 8:26-50.

Ledoux DR, Rottinghaus GE (1999) In vitro and in vivo testing of adsorbents for detoxifying mycotoxins in contaminated feedstuffs. In: Lyons, T.P., Jacques, K.A. (eds). Biotechnology in the Feed Industry. Nottingham University Press, UK, 369-379.

Rahaie S, Emam-Djomeh Z, Razavi SH et al. (2010) Immobilized Saccharomyces cerevisiae as a potential aflatoxin decontaminating agent in pistachio nuts. Braz $\mathrm{J}$ Microbiol 41:82-90.

Raju MVLN, Devegowda G (2002) Esterified-glucomannan in broiler chicken diets contaminated with aflatoxin, ochratoxin and T-2 toxin: evaluation of its binding ability (in vi- 
tro) and efficacy as immunomodulator. J Anim Sci 15:1051-1056.

SAS Institute (1992) SAS User's Guide: Statistics. SAS Institute Inc., Cary, N.C.

Scott PM (1990) Natural poisons. In: Helrich, K. (ed). Official methods of analysis of the Association of Official Analytical Chemists. Association of Official Analytical Chemists (AOAC), Arlington, V.A., 1184-1213.

Shetty PH, Hald B, Jespersen L (2007) Surface binding of aflatoxin $\mathrm{B}_{1}$ by Saccharomyces cerevisiae strains with potential decontaminating abilities in indigenous fermented foods. Int J Food Microbiol 113:41-46.

Stanley VG, Winsman M, Dunkley C et al. (2004) The impact of yeast culture residue on the suppression of dietary aflatoxin on the performance of broiler breeder hens. J Appl Poult Res $13: 533-539$

Associate Editor: Susana Marta Isay Saad

All the content of the journal, except where otherwise noted, is licensed under a Creative Commons License CC BY-NC. 